\title{
The Suspect Foreigner
}

\author{
By Elena Chiti
}

"Suspect" and "foreigner" may appear as synonyms in Egypt this year. A spokesperson of the Ministry of Interior, Abū Bakr 'Abd al-Karīm, invites the "respectable citizens" to report to the security forces all the "suspect elements" (al-'anāșir al-mushtabah bi-him) they encounter in their villages or neighbourhoods (al-'ANȘĀRI) [ $\nearrow T$ The Honourable Citizen]. Informing the state apparatus of their presence is a civic duty for everyone who is concerned "with the security of the country and its people" [ $\nearrow$ Security vs. Fear]. This duty is to be accomplished as soon as possible: promptness (al-musāra' $a$ ) is a key factor in these cases, for it enables security forces to effectively perform their task of protecting citizens.

No doubt, "reporting suspect elements" is a mission. But how does one recognize them? The indications given by the Ministry representative are vague enough to cover a wide range of situations, yet precise enough to apply to foreigners as a category. In fact, the "suspect elements" are the ones who do not fit in the ordinary routine of an Egyptian environment, because they look different, out of place, such as "individuals who are seen in a neighbourhood where they do not belong". As a result, an American student who is trying to practice his Egyptian dialect in Downtown Cairo is taken to the nearest police station, and similar cases occur when foreigners try to make contact with Egyptians. Passing by a café where a supposed foreigner sits together with Egyptians, a taxi driver says to his Egyptian customer, "Look, here they are again, these foreigners, brainwashing our youth!" (CHITI_FebMar).

While state-run media continue to associate foreigners with threats to national security, the fear of them grows in the public space. This increasing sense of distrust may push some "honourable citizens" to act directly as public defenders, instead of limiting themselves to warn the authorities. According to newspaper al-Watan, a young Danish journalist is "rescued by the police from the hands of the inhabitants" of Nāhiyā suburb "who tried to harm him because they were suspicious of him" (hâwwala l-i tidä' 'alayh lil-shakk fi 'amrih), because of "his presence during a march" (CHITI_Feb). In this framework, the police is portrayed as the protector of the foreigner who was in the weakest position, surrounded by a hostile crowd. However, the protection seems to encompass exclusively his physical safety. Not only the journalist's name, but also his picture and the pictures of all his documents appear on the newspaper, which seems less concerned with guaranteeing his anonymity than with the duty of reporting a potentially "suspect element".

All these cases follow a major incident, which marks the year. On January 25, Giulio Regeni, an Italian PhD student of Cambridge University and visiting scholar at the American University in Cairo, disappears [ 7 Disappearances]. He is heading to Downtown Cairo to meet a friend, but he never arrives to the appointment. He goes missing on the fifth anniversary of the 2011 revolution [ $\nearrow$ Commemoration / Memorial Days], in a climate of fear that oppresses Cairo and in particular the city centre, where the police is carrying out a massive wave of arrests to prevent demonstrations [ $\nearrow$ Downtown/Centre-ville]. For ten 
days, nobody is able to locate Regeni or his mobile phone. His dead body, found on February 3 on the Cairo-Alexandria desert road, bears clear signs of torture.

Egyptian authorities circulate all kinds of narratives around his death: Giulio Regeni shall have died in a car accident (ABŪ DAYF \& MUHAMMAD); or have been murdered in connection with a homosexual affair; or punished in an honour killing, by the husband, or the father, or the brother of one of his female conquests (TADROS; CHITI, Fieldwork notes, February-April 2016). Yet none of these versions explains the marks of torture, initially denied by the Egyptian justice (QARĀAA), but confirmed by the results of both the Egyptian and Italian autopsies [ $\nearrow$ True vs. False]:

Both document extensive torture - on the body, on the face. A broken neck. A broken skull. Slit ears; cigarette burn marks on the body. But the interesting discrepancy is the one that is included in the Italian autopsy report and omitted in the Egyptian one. And it has to do with fingernails. All his finger and toenails have been extracted. Now, this is a sign not only of torture; but torture to extract a confession. This is something that an intelligence service would do; not a terrorist organization. And it's interesting that this was omitted in the Egyptian report. (CBC Radio)

The only credible scenario is that Giulio Regeni was abducted by the Egyptian security forces and held for days in a secret place while being tortured to death, before someone decided to get rid of his body. Egyptian authorities spread other versions, according to which Regeni was a spy collaborating with British and/or American secret services that killed him once his mission was over (YOUTUBE, TAHRIRNEWS). His research about Egyptian unions is portrayed as either a tool for gathering sensitive information about Egypt, or a way of covering up more sensitive topics. His connections with both Cambridge University and the American University in Cairo are highlighted as a further confirmation of his dubious international contacts. In parallel, some Egyptian officials say Regeni was the victim of a conspiracy orchestrated by the Muslim Brotherhood to discredit Egypt in the eyes of its Western allies $($ WATANSIRB $)$ [ オSecurity $=$ Fear $($ Police State $)]$.

The divide between supporters and detractors of the Egyptian regime crystallizes around the case [ $\nearrow$ Clash]. The latter, Egyptians and foreigners, gather in front of the Italian Consulate in Cairo to show solidarity towards Regeni and his family, while calling for respect of human rights. They emphasize that Regeni's fate, although extraordinary for a foreigner, is the ordinary lot of thousands of Egyptians. One of the banners reads, "Giulio, one of us, killed like us". On the same tone, a commemoration is organized on February 24 at the American University in Cairo. A huge banner is hung which reproduces a famous cartoon by Italian artist Natangelo, portraying an Egyptian police officer trying to distinguish Regeni's body from all the Egyptians who were also tortured to death [ $\nearrow$ The Policeman Criminal]. An English sign reads, "Giulio's murder is not an isolated case" and then, addressing the murderers: "The AUC bubble will not protect you" (SHAMS EL-DIN). In fact, students and employees are revolting against the euphemistic tone of a first communiqué released by their institution, according to which "Giulio passed away". "Giulio didn't pass away, he was murdered," they repeat in private conversations as in official statements (EGYPTIANSTREETS) [ $\nearrow$ Voice vs. Silence]. At the same time, both the Egyptian academia and the foreign community in Egypt point to the strong economic and diplomatic bonds between Italy and

jais • 21 (2021) - Themed Section In2016: *258-*264 
Egypt, which ended up strengthening the Egyptian regime (ESTERMAN). Not only have the two countries always had flourishing commercial relationships, Egypt has also been able to buy Italian weapons that improved its military apparatus.

"Trade, business, geography, geopolitics, and wars. Since Caesar's time, it has been hard to find two countries on the shores of the Mediterranean as connected as Egypt and Italy," writes an Italian journalist (TRAMBALLI). Many Egyptians seem to share this feeling. Sacd alDīn Ibrāhīm, president of the Ibn Khaldun Center for development studies, states that "the relationship between Italy and Egypt is one of the strongest in the Northern Mediterranean and we should not forget that Egypt is Italy's second partner in the economic field" (al$B A W W \bar{A} B A)$. A writer says Italy has always been Egypt's first commercial partner and this resulted in a solid connection that goes beyond the economic sphere. "My daughter grew up with Chicco products, in a Chicco stroller: it does mean something!" a woman declares (ChITI_March). Yet Regeni's case casts a shadow over both the cultural and the economic cooperation between the two countries. On February 3, a "delegation of important Italian businessmen" (wafd min kibār rijāl al-a'māl al-'ît țalìyyìn), led by Minister of Economic Development Federica Guidi, is visiting Egypt. The Ministry interrupts the visit after Regeni's body is found (al-SHARQ). At the beginning of April, Italy recalls its ambassador judging the Egyptian investigations unsatisfying (al-ZANĀTĪ). In June, it blocks the military deal with Egypt to protest over the lack of cooperation of Egyptian authorities (CNN, REUTERS, AL-JAZEERA). The spectre of a commercial boycott haunts Egyptian politics and Egypt desperately seeks to normalize ties with Italy and Europe. In one of his speeches, president Sisi claims that Egypt has also its own "Regeni": "a son who disappeared there", in Italy, and the Italian investigators have not elucidated the case yet (al-Sīsī). Initially presented as a young man, the disappeared Egyptian is in fact a middle-aged man, whose son is a University student that cannot go to Italy to look for his father because of the exams ('AZZĀM). Other parallels are found outside of Italy. For months on end, newspapers report news of young Egyptians who disappeared outside of Egypt. One after the other, these "Egyptian Regenis," as they are called, give the impression that what happened to Regeni was nothing but a terrible incident, something that may occur in every country to people who, coming from abroad, find themselves in a rather unsafe position [ $\nearrow$ Migration]. Titles emphasize the unclear circumstances of their death and the doubtful injuries they show:

An Egyptian Regeni in London. Mystery surrounds Sharîf Habīb's killing... (FATH̄̄)

A new Egyptian Regeni in America. His body, found in a dumpster, bears signs of torture (al-YAWM al-SĀBI)

Sometimes, Giulio Regeni's picture is published alongside the one of an "Egyptian Regeni." The physical resemblance between the two provokes an emotional reaction, which is meant to reveal the lack of interest for the Egyptian citizen, compared to the international attention on the Italian. A hashtag is created on Twitter that openly asks the question: "What if Regeni

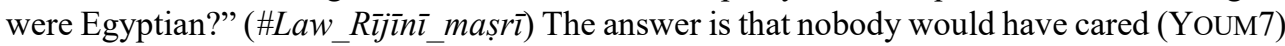
[ ZInferiority $v$ s. Superiority].

This bitter feeling is widely shared. In the months that follow Regeni's murder, with the devaluation of the Egyptian pound accompanying a series of shortages of food, medicines, and basic products [ $\nearrow$ Dollar Crisis], many people are exhausted of hearing about Regeni.

jais • 21 (2021) - Themed Section In2016: *258-*264 
They see the diplomatic pressure on Egypt as an unfair punishment on the part of the West, which still uses imperialist methods to pursue its goals. The media coverage of the case has a lasting impact on the reputation of Egypt, which appears to be an unsafe country at a time when it is most in need of attracting tourists [ $\nearrow$ Tourist Resorts]. Looking at the hotel's reservation log, almost empty, an employee complains:

This Regeni's thing... all these problems for just one person ('ashān fard)? And not just with Italy, now even with Europe in general! I'm really astonished when I see that this story isn't over. We also have a young Egyptian disappeared there [in Italy] and we don't make all this fuss. We have so many Egyptians who died abroad, in Jordan, in Saudi Arabia. I do remember in the past I read newspapers with fake reports saying they died out of brain strokes or heart strokes. All these young men?! Then I asked a Jordanian guest at the hotel and he told me they all got killed. In honour crimes. And the governments covered things up. (CHITI_Apr-Jun)

While this view seems to be largely spread, it is not universally shared. Along with the comparison between Europe and Egypt, Regeni's case sparks reflections about the present state of the country and the hopes aroused by the 2011 revolution [ $\nearrow$ Past vs. Present]:

In a coffee shop across the Alexandrian Corniche, a man asked why Italy is still making a fuss about Regeni. A patron stood up in the corner and yelled, "Because that's what it looks like when a country actually cares for its own citizens." An eerie silence followed. An evocative reminder why, some 50 metres away from the same coffee shop, Khaled Saeed was killed by two police officers almost six years ago, and his death mattered then - surely mattered enough for a revolution to be sparked. The same revolution's fifth anniversary that saw Regeni go missing. (ALI)

Since the very beginning, Egyptian authorities strive to avoid parallels with the Mubarak era. They want to show that Egypt has changed since then, ruled by an elite that is both concerned with human rights and trustworthy for its Western allies. They need to prove they are handling the case rapidly and efficiently. Some three days after the discovery of Regeni's body, they announce the arrest of two people, reported to be responsible for his death, yet not linked to the Egyptian security apparatus or to any terrorist organization ('ABD AL-RĀDI, ELYOMNEW). Even if the two are proven extraneous to the facts, the authorities maintain the narrative of common criminals who would have kidnapped Regeni for money. This version is sealed in blood when, two months later, the police open fire on five men within a car: Șalāh 'Alī, Țāriq 'Abd al-Fattāḥ, Sa'd Ṭāriq, Muștafà Bakr, and Ibrāhīm Fārūq. None survives, while officials rush to say they were all involved in Regeni's murder. Pictures are released of Regeni's passport, university ID, and credit card supposedly found at the apartment of one of the five, along with stolen phones - yet there are no traces of Regeni's one. A red bag bearing the Italian flag and some forged police IDs complete the setting. The authorities claim the gang of five was specialized in kidnapping foreigners for a ransom, sometimes disguised as police officers to approach them without raising suspicion. The families of the five victims immediately contest this version. Rashā Țāriq, who lost in the car husband, father and son, says her relatives could not speak any foreign language in order to approach foreigners. She

jais • 21 (2021) - Themed Section In2016: *258-*264 
thinks the police deliberately placed Regeni's belongings in the flat (EL SIRGANY), while Regeni's relatives assert the bag was not Regeni's [ $\nearrow$ True $\boldsymbol{\nu s .}_{\text {s. False]. }}$

On social media, some people protest against what appears as a plot of the Egyptian state against five of its citizens [ 7 "The System" vs. "The People"]. A campaign is launched to contrast the propaganda narrative, under the hashtag "Haqq al-khamsa qabla haqq Rỉjin $\vec{\imath}$ " ("The right of the five before the right of Regeni") [TWITTER] [ $\nearrow$ Social Media]. Twitter users speak up against the official discourse, showing distrust towards the regime and solidarity towards the five: "None of them are criminals. Egypt regime killed them to accuse them of killing," "Egyptian thug regime kidnapped five people randomly and killed them. Later they accused them of killing Regeni." Sometimes, statements are explicitly in line with the hashtag slogan, as they seem to prioritize the rights of the Egyptians over those of a single foreigner. Other people react to this competition over human rights, putting the Egyptians and the foreigner in the same boat: "Haqq al-khamsa wa-haqq Rìjini wa-haqq al-shuhadä" ("The right of the five, the right of Regeni and the right of the martyrs"). However, a confrontation continues to be seen between Italy and Egypt. Symbolically, it takes on the proportion of a clash between ruthless West and underprivileged Arab world: "Italy Gov. will compromise by receiving $\$$ billions of the food and butter budget of poor Egyptians" [ $\lambda$ Inferiority $v$ s. Superiority].

Although Westerners in general look suspect, Italians find themselves in the most delicate position: "Regeni's murder undermined the relative safety Italians have long enjoyed in Egypt. No one is off-limits in an insecure security state" (ALI). Indeed, while Italians were once perceived as a brother people, united to Egyptians by a common belonging to the Mediterranean space, an Italian passport arouses now particular suspicion. "So you're Italian," says a police officer checking IDs in Downtown Cairo [ $\nearrow K a m \bar{n} n$ ], "Should I be afraid of you?" "Where are you from?" asks a man in plain clothes in the middle of the street and leaves as he obtains the information. "One shouldn't say 'I'm Italian' in the middle of the street these days," an Egyptian woman advises, "Pick an Arab nationality, dear, say you're Lebanese" (CHITI_Feb) [ $\nearrow$ Dual Identities / Masking].

The topic is no less sensitive in the literary field. At the Sheikh Zayed Book Fair, a publisher refuses to be interviewed by "another Italian researcher" with quite an ambiguous formula: "We won't have time for an interview anyhow." When asked for the reason, since the Book Fair does not close until late at night, he makes his point clearer: "Italian researchers don't live that long in our country, you see." On the same day at the same place, an interview with another publisher risks turning into a series of diplomatic statements:

Our government did not want this. The two countries are friends, united by commercial and cultural bonds. We are sorry for what happened. Please tell Italy not to stop buying from us and not to boycott our country...

We were talking about best-sellers...

Since we are here, I would like to take the opportunity to tell that we are sorry and ask you to tell Italy not to stop... (CHITI_Apr)

The relationship between Egyptians and foreigners, this year, may sometimes resemble a vicious circle $[$ ᄀ Present $=$ Past $($ Stuck $)]$. 


\section{Related Entries}

ARraYs - Clash Commemoration / Memorial Days Disappearances Dollar Crisis Downtown/Centre-ville $\downarrow$ Dual Identities / Masking $\downarrow$ Kaminn $\downarrow$ The Honourable Citizen $\downarrow$ Migration - The Policeman Criminal Social Media $\downarrow$ Tourist Resorts

CODES - Inferiority vs. Superiority Past vs. Present $\downarrow$ Security vs. Fear "The System" vs. "The People" True vs. False Voice vs. Silence

CODES COLLAPSED - Present $=$ Past $($ Stuck $) \downarrow$ Security $=$ Fear $($ Police State $) \downarrow$ True $=$ False $($ Life in Limbo)

\section{References}

'ABD AL-RĀḌ̄, Maḥmūd. "Bi-l-șuwar: Ba'da murūr 50 yawman... al-Dākhiliyya tafukk țalāsim hāāith al-shābb al-'̄ịtạlī... Quwwāt al-'amn taqtul al-muttahamīn bi-sariqat Rīǧīnī wa-ta thur 'alà jawāz safarih... al-Tashkīl takhașșaș fî 'ntihāā șifat al-ḍubbāt wa-sariqat al-'ajānib... wa-Rūmā tashkur al-

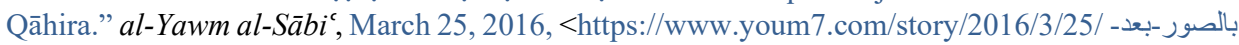

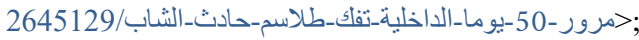

ABŪ ḌAYF, B., and W. MuHAMMAD. "Amn al-Jīza: al-ịtālī al-mukhtafì tawaffà bi-ḥādith sayr wa-ikhṭār al-sifăra li-tasallum al-juththa." Al-Yawm al-Sābic, February 4, 2016 (no longer available online).

Ali, Amro. "Giulio and the Italians of Egypt." MadàMașr, April 4, 2016, <https://www.madamasr. com/en/2016/04/04/opinion/u/giulio-and-the-italians-of-egypt/>.

al-'ANȘĀRT̄, Ǧihād. "Bil-fĩdiyū... al-Dākhiliyya: «'Alà 'al-muwāținīn al-shurarā’” ’iblāghunā 'an almushtabah bihim»." Mișr al-'Arabiyya, Media, February 7, 2016, <https://m.masralarabia.net/

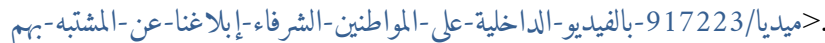

'AzZĀM, 'Amānī. "Nijl al-mișrī al-mukhtafĩ fî̀ 'Îțāliyā lil-Sīsī: 'Bușṣ̂-lnā yā rayyis, mahaddish mihtamm bīnā'." al-Wațan, March 16, 2016, <https://www.elwatannews. com/news/ details/ 1027825>.

[al-BAWWĀBA =] N. N. "Sacd al-Dīn Ibrāhīm: Tașrīhạāt al-ḥukūma ḥawla maqtal Rīğīnī mutaḍāriba." alBawwāba, April 9, 2016, <http://www.albawabhnews.com/1871238>.

$[C B C$ Radio $=]$ N. N. "Day 6: Were Egyptian security forces responsible for Italian grad student Giulio Regeni's death?" CBC Radio, Feb 12, 2016, <http://www.cbc.ca/radio/day6/episode-272-jianghomeshi-trial-pope-francis-in-former-murder-capital-lebron-james-tattoos-and-more1.3444087/were-egyptian-security-forces-responsible-for-italian-grad-student-giulio-regeni-sdeath-1.3444217>.

CHIтI, Elena. Fieldwork notes. Egypt 2016. (Unpublished).

$[C N N=]$ N. N. "Mișr tarudd 'alà qarār 'İțālìyā bi-ta' līq tawrīd qița ' ghiyār țầirāt F-16 lahā ba'da qaḍiyyat Rịḡinī: taṣīid ghayr mubarrar wa-yajib murāāat al-mașāliḥ." CNN bil-'arabiyya, July 12, 2016, $<$ https://arabic.cnn.com/middleeast/2016/07/12/egypt-italy-tensions-f-16-spare-parts-regini>.

[EGYPTIANSTREETS =] N. N. "AUC Students, Professors Mourn Death of Giulio Regeni Amid Concerns Over Academic Freedom.” Egyptian Streets, Feb. 18, 2016, <http://egyptianstreets.com/2016/02/18/ auc-students-professors-mourn-death-of-giulio-regeni-amid-concerns-over-academic-freedom/>.

EL SIRGANY, Sarah. "Italian student's killing pulls Egyptian family into web of deaths, dead ends." CNN, April 21, 2016, <https://edition.cnn.com/2016/04/21/middleeast/egypt-italy-giulio-regenimystery/index.html>.

[ELYOMNEw =] N. N., al-Yawm al-Jadīd, February 2, 2016, <http://www.elyomnew.com/news/24 hours/2016/02/06/44364> (no longer available online).

Esterman, Isabel. "On Giulio and the cost of doing business in Egypt." MadàMașr, Feb. 10, 2016, <https:// www.madamasr.com/en/2016/02/10/opinion/u/on-giulio-and-the-cost-of-doing-business-in-egypt/>.

jais • 21 (2021) - Themed Section In2016: *258-*264 
FATḤī, Nağlā'. "Mabāḥith tamwīn al-Minyā taḍbuṭ mașna ' 'asal maghshūsh wa-yuḍbaṭ 18 țunn." alDustūr, November 29, 2012, <https://www.dostor.org/1049393>.

ḤAMDĪ, Mușțafà, and Walīd NĀGĪ. "al-Niyāba: āthār ta dhīb bi-juththat al-shābb al-îțâlī... wa'l-mabāḥith: 'hāäith sayr' wa-lā shubha jinā’iyya." al-Shurūq online, February 5, 2016, <https://www. shorouknews. $\mathrm{com} /$ news/view.aspx?cdate $=05022016 \& \mathrm{did}=054379 \mathrm{af}-383 \mathrm{~d}-4 \mathrm{~d} 43$-a5df-c93a9339f451>.

[al-JAZEERA =] N. N. "Tashrīi 'īṭālī yamna tazwīd Mișr bi-mawaddāt 'askariyya." al-Jazeera, June 30, 2016, >https://www.aljazeera.net/news/international/2016/6/30/تشريع-إيطالي-يمنع-تزويد-مصر -بمعدات "

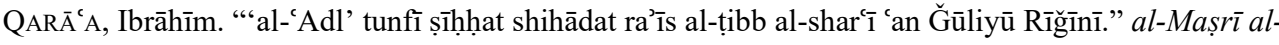
Yawm (online), March 1, 2016, <https://www.almasryalyoum.com/news/details/902178>.

REUTERS Staff. "Italy votes to halt aviation supplies to Egypt over student death." Reuters, June 29, 2016, <https://www.reuters.com/article/us-egypt-italy-regeni/italy-votes-to-halt-aviation-suppliesto-egypt-over-student-death-idUSKCN0ZF2EH>.

SHAMS EL-Din, Mai. "AUC remembers Giulio Regeni, protests university's position on his murder." MadàMașr, Feb. 25, 2016, <https://www.madamasr.com/en/2016/02/25/feature/politics/aucremembers-giulio-regeni-protests-universitys-position-on-his-murder/>.

[al-SHARQ =] N. N. "Gārdiyān [The Guardian]: Warā’a maqtal Rīğīn̄̄ fī Miṣr 'faḍịha'." al-Sharq, Feb. 24, 2016, >https://www.al-sharq.com/article/24/02/2016/مصر-في-ريجيني-مقتل-وراء-الفضيحة-جارديان.

al-Sīsī, 'Abd al-Fattāḥ. Speech, April 13, 2016.

TADROS, Sherine. "Egypt Defies Italy Over Regeni Murder Probe: Italy recalls its ambassador over a 'lack of co-operation' from Egypt in a murder probe into the death of a Cambridge student." sky news, April 10, 2016, <https://news.sky.com/story/egypt-defies-italy-over-regeni-murder-probe10238116>.

[TAHRIRNEWS =] N. N. " 'Azmī Muğāhid: Rìjīin̄ 'amīl lil-mukhābarāt al-inkilīziyya wa-qatalat-hu ba damā anhà mahammatahū." TahrirNews, [2016], <https://www.tahrirnews.com/posts/406755/> (no longer available online).

Tramballi, Ugo. "Italy and Egypt no more business as usual." ISPI [Istituto per gli studi di politica internazionale], Commentary, May 30, 2016, <https://www.ispionline.it/it/pubblicazione/italy-andegypt-no-more-business-usual-15153>.

[TwITTER =] \#Haqq_al-khamsa_qabla_haqq_Rīğīin̄, >https://twitter.com/hashtag/حق_الخمسه_قبل_حق_ريجيني > > (no longer available).

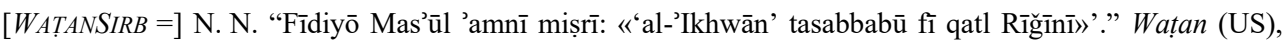

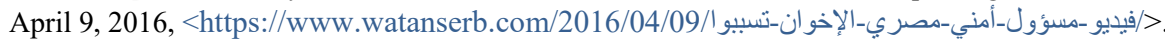

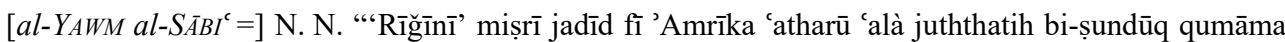
wa-'alayhā 'āthār ta'dhīb." al-Yawm al-Sābi', April 28, 2016, <https://www.youm7.com/story/

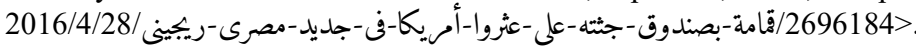

[YOUM7 =] N.N. “Law Rījīnī mașrī [...].” al-Yawm al-Săbic, [2016] <http://parlmany.youm7.com/News/5/ 64280/ومحدش-مات - كان-ومغردون-تويتر-يشعل -تريند-مصرى-ريجينى > (no longer available online).

[YOUTUBE =] $<$ https://www.youtube.com/watch? $\mathrm{v}=$ ociynMzACoI $>$ (no longer available online).

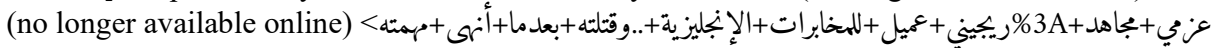

al-ZANĀTī, Ḥusayn. "Safïr 'Ītāliyāa ‘āda 'ilà Rūmā ba'da 'stid'ẩ ḥukūmatih.” Al-Ahrām, April 11, 2016.

४ elena.chiti@su.se 